\title{
MAKNA SYAIR “NYAWA-KU DIBERIKAN BAGIMU NKI 49" YANG IDE SYAIRNYA TERINSPIRASI DARI TULISAN DI BAWAH LUKISAN YESUS BERMAHKOTA DURI KARYA FRANCES RIDLEY HAVERGAL
}

\author{
Stepanus Lajan \\ Sekolah Tinggi Filsafat Theologia Jaffray Makassar
}

stev270994@gmail.com

\begin{abstract}
The song of My Life is given to you is a song that is very blessing but has become an unanswered conversation among God's servants, about the lyrics of songs that have inappropriate teaching if the meaning contained in the lyrics is misinterpreted. The phrase that becomes the question is "My life is given to you, do you speak to Me"? The purposes of writing this scientific work are, First, to find out the poetry idea for the song "My Life is Given to You" (NKI 49) which was inspired by the writing under the painting of Jesus with the crown of thorns before Pilate? Second, to find out the main meaning contained in the lyrics of the song "My Life was given to you." The method used in researching scientific works is the library method which includes: the Bible, books, dictionaries, and journals, plus online journals, ebooks, articles, which are related to the topics discussed. Conclusion The song "My Life is given to you" NKI 49, is the work of Frances Redley Havergal, whose music was composed by the composer Philip Paul Bliss. His poetry writing idea was inspired by a painting by Sternberg called "Ecco Homo" in a German art gallery, Dusseldrof. Under the painting depicting Jesus with the crown of thorns before Pilate, there is an inscription that reads: "This I did for you, what did you do for me?" This phrase expresses selfdedication, affirming the believer's faith to commit to fully giving life to Jesus. The phrase "what do you give me," is an important part of this song, because it encourages believers to apply the sacrifice of Jesus in their lives to become persons who glorify God. Believers are not required to be reciprocated from the work of Christ, but human responsiveness accepts the atonement or sacrifice that is made in the lives of fellow humans.
\end{abstract}

Keywords: Meaning; Life; Poetry; Inspiration; Idea.

\begin{abstract}
ABSTRAK
Nyanyian Nyawa-Ku Di Berikan Bagimu merupakan lagu yang sangat memberkati namun menjadi sebuah perbincangan yang belum terjawab tuntas dikalangan hamba Tuhan, tentang syair dari lagu yang memiliki pengajaran yang kurang tepat jika disalah artikan makna yang terkandung dalam syair. Frasa yang menjadi pertanyaan adalah "nyawa-Ku diberikan bagimu apa kau b'ri pada-Ku"? Adapun tujuan penulisan karya ilmiah ini adalah, Pertama, untuk mengetahui ide syair lagu "Nyawa-Ku Diberikan Bagimu" (NKI 49) yang terinspirasi dari tulisan di bawah lukisan Yesus bermahkota duri dihadapan Pilatus? Kedua, untuk mengetahui pokok makna yang terkandung dalam syair lagu "Nyawa-Ku Diberikan Bagimu." Metode yang digunakan dalam penelitian karya ilmiah ini adalah metode kepustakaan yang di dalamnya meliputi: Alkitab, buku-buku, kamus, dan jurnal, ditambah dengan jurnal online, ebook, artikel, yang berhubungan dengan topik yang dibahas. Kesimpulan Nyanyian "Nyawa-Ku Diberikan Bagimu" NKI 49, merupakan karya Frances Redley Havergal, yang musiknya digubah oleh komposer Philip Paul Bliss. Ide penulisan syairnya terinspirasi lukisan karya Sternberg yang diberi nama "Ecco Homo" dalam sebuah galeri seni Dusseldrof Jerman. Di bawah lukisan bergambar Yesus bermahkota duri di hadapan Pilatus itu, terdapat tulisan berbunyi: "Ini Aku lakukan untuk kamu, apa yang kamu lakukan untuk aku?" Frasa ini mengekspresikan pengabdian diri, mengokohkan iman orang percaya untuk berkomitmen memberi hidup sepenuhnya kepada Yesus. Frasa "apa kau beri pada-Ku," menjadi bagian penting dalam lagu ini, karena mendorong orang percaya mengaplikasikan pengorbanan Yesus dalam kehidupannya agar menjadi pribadi yang memuliakan Allah. Orang percaya tidak dituntut timbal balik dari karya Kristus, namun responsif manusia menerima pendamaian atau pengorbanan itu dilakukan dalam kehidupan sesama manusia.
\end{abstract}

Keywords: Makna; Nyawa; Syair; Inspirasi; Ide. 


\section{PENDAHULUAN}

Musik merupakan bagian yang tidak terpisahkan dari kehidupan manusia dan sudah menjadi sebuah kebutuhan hidup. Pada dasarnya musik dapat dikatakan sebagai multi fungsi, karena bisa menjadi media ekspresi emosi, kenikmatan estetik, hiburan, alat komunikasi, simbol dalam masyarakat, respon fisik, pengesahan institusi sosial dan ritual agama, kontribusi untuk pengembangan dan pelestarian kebudayaan. ${ }^{1}$

Salah satu fungsi di atas menjadi pilihan penulis untuk pembahasan dalam tulisan ini, yaitu dari sisi ritual agama. Seperti diketahui dalam ritual kekristenan, musik atau nyanyian adalah unsur liturgi yang sangat berperan dalam ibadah. Selain untuk mendukung tatanan liturgi, secara khusus nyanyian menjadi sarana memuji dan menyembah Tuhan dalam kehidupan orang percaya.

Ada tiga bentuk nyanyian yang dikenal di kalangan jemaat gereja, yaitu: nyanyian mazmur, kidung puji-pujian atau himne, dan nyanyian rohani. Masing-masing nyanyian ini mempunyai ciri khas, baik dari bentuk penulisan sastranya, maupun tujuan, serta isi berita dalam syair, akan tetapi jemaat secara umum menyebut ketiga nyanyian sebagai nyanyian hymn saja. Nyanyian himne adalah amanah atau perintah Alkitab, hendaknya hal ini tidak diabaikan. ${ }^{2}$ Namun dapat dilihat, dalam perkembangan nyanyian gereja sekarang tak dapat dipungkiri, bahwa pada beberapa gereja ada kecenderungan pergeseran dalam penggunaan nyanyian-nyanyian ibadah, dari nyanyian himne menjadi nyanyiannyanyian baru yang betul-betul baru. Rupanya pemahaman para musisi atas nas yang mengatakan: "Nyanyikanlah nyanyian baru bagi Tuhan" (Mzm. 96:2), diartikan sama dengan membuat lagu baru yang sungguh-sungguh baru; serba baru, baik melodinya, teksnya, iramanya, maupun gaya menyanyikannya, semua utuh tampilan yang benar-benar baru.

Apakah ada yang salah di situ? Tentu saja tidak, itu sah-sah saja, karena setiap orang mempunyai karunia dan inspirasi untuk berkarya (1 Kor. 14:26); hanya perlu diingat bahwa "nyanyian baru" bukanlah hal yang fisik saja, tetapi lebih kepada sikap hati. ${ }^{3}$

Sesungguhnya kalau mau jujur, maraknya penggunaan lagu-lagu baru dalam ibadah diam-diam telah menimbulkan kekuatiran bagi sebagian jemaat, karena secara tidak langsung telah mengurangi minat menyanyikan himne yang selama ini sudah mendarahdaging dalam kehidupan jemaat. Pro kontra tidak dapat dihindari, sikap jemaat sudah terbagi antara mereka yang menyambut dengan terbuka lagulagu pop rohani dalam ibadah, dengan mereka yang tetap setia dan mencintai hymn untuk nyanyian ibadah.

Terlepas dari fenomena di atas, hal pokok yang hendak dibahas pada kesempatan ini bukanlah soal pergeseran atau perbedaan maupun pro kontra tentang nyanyian himne dan nyanyian atau lagulagu baru, tetapi hanya untuk mengawali pembahasan yang berkenaan dengan himne sebagai nyanyian gereja atau nyanyian ibadah.

Mengapa nyanyian himne begitu penting? Karena himne memiliki kekuatan teologis yang dalam. Himne adalah nyanyian yang dinaikkan untuk mengekspresikan pengagungan dan penyembahan kepada Tuhan. ${ }^{4}$ Seperti yang dikemukakan Ronald Allen, himne adalah salah satu cara terbaik untuk mengajar kebenaran kepada umat Tuhan karena di dalamnya ada Firman Tuhan. ${ }^{5}$

\footnotetext{
${ }^{1}$ Inggit Sitowati, "Relevansi Selera Musik Klasik dan Kelas Sosial," Jurnal Musik 2, no. 1 (Agustus 2010): 11, https://repository.uksw.edu/bitstream/123456789/2813/2.

${ }^{2}$ Calvin, M. Johannson. Discipling Musik Ministry Twenty-First Century Directions (America: Hendrickson Publisher, 2002), 123.

${ }^{3}$ Johansson, 124.

${ }^{4}$ Ibid, 124.

${ }^{5}$ Jonathan Tanujaya, "Menjadi Pemimpin Musik Gereja Yang Handal," Voice of Wesley: Jurnal Ilmiah Musik dan Agama 2, no. 2 (25 November 2019): 3, https://doi.org/10.36972/jvow.v2i2. Ronald Allen, Worship Rediscovering the missing Jewel (America: Multhomah Press, 1982), 59. 
Lagu-lagu himne merupakan nyanyian yang sangat penting untuk dianalisa oleh karena unsur teologi yang terkandung di dalamnya memberi dorongan bagi orang percaya bertumbuh dalam iman kepada Yesus. Himne, adalah artikulasi yang mumpuni dan ekspresi yang mendalam melalui perangkat kesusastraan yang dipakai, di mana tujuan dari semuanya itu bukan hanya sekadar didaktik (instruktif), tetapi justru untuk menggugah adanya suatu pengalaman devosi kepada Tuhan. ${ }^{6}$

Biasanya himne-himne yang terdapat dalam buku nyanyian dan menjadi nyanyian resmi dalam satu gereja, memiliki kriteria yang cukup lengkap. Mulai dari judul, nomor, pengarang, tanda-tanda musik, serta sumber asli, semua tercantum secara tematis. Oleh sebab itu, sangat membantu jika menggunakan sumber buku yang resmi. Jika memilih sebuah himne yang disukai atau ingin diketahui serta dikenal lebih jauh lagi tentang himne dimaksud, maka dengan mudah dapat dicari dan ditemukan melalui tematik lagu; bahkan jika tidak diketahui pun judul atau nama lagu, dengan mudah juga dapat dilacak lewat notasi atau solmisasi dari melodi awal lagu, karena semua sudah terdaftar dan tersusun dalam buku nyanyian.

Hal ini menjadi salah satu perbedaan antara nyanyian himne yang dipahami sebagian jemaat dengan lagu-lagu baru, karena lagu-lagu baru meskipun dapat dikategorikan sebagai himne, tetapi belum tercetak dan tersusun secara tematik sebagaimana pada buku nyanyian, melainkan hanya kumpulan lagu-lagu yang masih acak dan belum tersusun secara tematis.

Selama penulis berjemaat di gereja yang menggunakan buku Nyanyian Kemenangan Iman atau NKI, ada satu lagu yang penulis sukai dan sangat menarik perhatian, sehingga penulis ingin mengenal serta mengetahui apa yang menjadi latar belakang terciptanya lagu. Dikarenakan disetiap ibadah perjamuan kudus lagu ini selalu dibawahkan menarik perhatian penulis bahwa setiap karya memiliki kisah di balik sebuah lagu, maka lagu yang menjadi fokus penulis yaitu "Nyawa-Ku Diberikan Bagimu" (NKI 49), tentulah mempunyai cerita tersendiri yang dapat dikaji dalam penulisan karya tulis ini.

Himne "Nyawa-Ku Diberikan Bagimu" karya Frances Ridley Havergal terdiri dari empat bait, tiap baitnya berisi empat baris, dan dua baris terakhir pada setiap bait merupakan kor atau reffrein, dengan syair yang sama, yaitu: “nyawa-Ku dib'rikan bagimu, apa kau b'ri pada-Ku?" Konon, teks atau syair ini sudah lama menjadi perbincangan atau perdebatan yang berujung pada pertanyaan yang tidak pernah terjawab tuntas, baik oleh hamba-hamba Tuhan serta para tokoh gereja maupun para musisi gereja. Barangkali pertanyaan yang tak terjawab adalah bagian dari syair "nyawa-Ku dib'rikan bagimu, apa kau b'ri pada-Ku?" apakah benar, Yesus telah menuntut langsung atas pengorbanan-Nya kepada manusia, dalam hal ini jemaat?

Pertanyaan tersebut membuat penulis merasa tertantang untuk mengetahui lebih jauh dan lebih dalam lagi akan latar belakang himne ini, dan hal-hal yang terkandung di dalamnya. Juga yang menjadi tanda tanya adalah, sebagai nyanyian jemaat, nyanyian ini selalu dibawakan atau dinyanyikan hanya pada ibadah perjamuan kudus.

\section{TINJAUAN PUSTAKA}

\section{Ide dan Inspirasi}

Dalam Kamus Besar Bahasa Indonesia, pengertian ide diartikan sebagai gagasan, pikiran, pendapat. ${ }^{7}$ Secara umum, ide adalah rancangan yang tersusun dalam pikiran. Ide bisa datang atau timbul dari pemikiran diri sendiri atau individu, tetapi bisa juga timbul dari sekelompok orang yang memiliki pemahaman atas sebuah maksud dan tujuan yang hendak dicapai.

Sedangkan inspirasi, masih oleh Kamus Besar Bahasa Indonesia diartikan sebagai ilham. Secara umum, inspirasi merupakan sebuah proses yang mendorong seseorang tergerak untuk berbuat

\footnotetext{
${ }^{6}$ Samuel Tandei, "Tinjauan Historis Perkembangan Musik Gerejawi Didalam Gereja-Gereja Independen (Free Churches) dan Implikasinya Bagi Penatalayanan Musik Gerejawi Di Masa Kini (1)," Veritas : Jurnal Teologi dan Pelayanan 15, no. 1 (18 Januari 2020): 88, http://Repository.Seabs.Ac.Id/Handle/123456789/299.

${ }^{7}$ Kamus Besar Bahasa Indonesia, s.v. "ide."
} 
sesuatu yang kreatif. Biasanya inspirasi bisa datang atau timbul dengan sendirinya atau bisa juga setelah melihat atau menyaksikan, dan mengamati sesuatu keadaan atau situasi atau tempat yang jarang terpikirkan. ${ }^{8}$

\section{Pengertian Syair}

Syair adalah satu puisi ${ }^{9}$ yang dirangkai lewat tulisan yang memiliki untaian nada yang harmonis bagi kalimat-kalimat yang tersusun dari satuan-satuan bunyi tertentu serta unsur ekspresi rasa dan imajinasi yang lebih dominan. ${ }^{10}$ Suatu tulisan yang cenderung berisi kisah, ceritera, soal agama, dan sejarah peristiwa yang memiliki pesan, ${ }^{11}$ yang diungkapkan dengan bentuk sajak yang teratur, dapat dimengerti dan dipahami. Jika dipadukan dengan musik, maka pesan tersebut akan terlihat oleh karena disesuaikan dengan karakter yang di dalamnya.

Jadi syair adalah sastra yang menggunakan kata-kata yang kaya akan makna, baik dalam bentuk simbolik mau pun denotatif. Susunan syair biasanya disusun dalam bentuk bait, yang terdiri empat baris dengan metrik yang berbeda-beda, tetapi dalam kesatuan saling mengikat.

\section{Himne}

\section{Pengertian Himne}

Menurut Ensiklopedi Musik, hymn asalnya dari kata hymnus, atau secara bahasa Inggris dieja menjadi himne, yakni musik yang berkembang di gereja, merupakan salah satu pengantar ibadah, yang di dalamnya terkandung pengertian sajak-sajak pujian kepada Allah. ${ }^{12}$ Kamus Besar Bahasa Indonesia, mengartikan himne sebagai nyanyian pujaan kepada Tuhan. ${ }^{13}$ Himne adalah puisi yang dinyanyikan, atau puisi yang berisi pujian kepada Tuhan. ${ }^{14}$ Tetapi, ada juga yang mengartikan himne sebagai nyanyian pujian yang menunjukkan keterkaitan antara prinsip-prinsip teologis dari iman Kristen dengan bentuk syair yang membangun intelektual umat ke dalam ibadah yang membangkitkan emosi. ${ }^{15}$ Singkatnya, hymn adalah puisi yang dinyanyikan, atau puisi yang berisi pujian kepada Tuhan. ${ }^{16}$

Dengan beberapa pengertian di atas, maka dapat disimpulkan, bahwa hymn atau himne adalah nyanyian pujian yang dipersembahkan kepada Allah sebagai media penghormatan kepada Juruselamat dalam posisi tertinggi pada kehidupan manusia. Menjadi jembatan dalam membangun persekutuan dan hubungan antar umat dengan Tuhan. Nyanyian yang mengingatkan orang percaya akan karya Allah dalam Yesus Kristus.

\section{Kekuatan Himne}

Kekuatan himne sebagai nyanyian pujian yang ditejemahkan ke dalam bentuk estetika dan artistik yang kuat, teoritis, sangat doktrinal dengan kebenaran yang proporsional, mensistematisasikan pengajaran dan atau peninjauan kembali ajaran-ajaran besar dari kitab suci. ${ }^{17}$ Juga sangat memungkinkan komunitas penyembah untuk menceritakan kembali kisah aspek historis dari iman, dan seringkali secara simultan menunjuk ke zaman mesianik.

Himne dapat menampilkan konten teologis yang bersifat menyeluruh dan memiliki kemampuan untuk mengontekstualisasikan penekanan khusus dalam bahasa yang relevan. Sangat tepat digunakan dalam ibadah Kristen karena mereka berpusat pada Tuhan dari pada diri sendiri. Sifatnya agung, menunjukkan penekanan teologis sambil mempertahankan sentralitas Allah sebagai subjek. Himne

${ }^{8}$ Kamus Besar Bahasa Indonesia, s.v. "inspirasi."

${ }^{9}$ Akmal, "Kebudayaan Melayu Riau (Pantun, Syair, Gurindam),” Jurnal Dakwah Risalah 26, no. 4 (15 Desember 2015): 160, https://doi.org/10.24014/jdr.v26i4.1283.

${ }^{10}$ Hasbullah, Ahmad Syai, dan Nurlaili Nurlaili, "Mebobo Pada Adat Perkawinan Suku Kluet Desa Malaka Kecamatan Kluettengah Kabupaten Aceh Selatan," Jurnal Ilmiah Mahasiswa Pendidikan Seni, Drama,

Tari \& Musik 1, no. 1 (2016): 31, http://www.jim.unsyiah.ac.id/sendratasik/article/view/5237.

${ }^{11}$ Pringgodigdo, Ensiklopedi Umum (Yogyakarta: Kanisius, 1991), 1068.

${ }^{12}$ Ensiklopedi Musik (Jakarta: Delta Pamungkas, 1997), 227.

${ }^{13}$ Kamus Besar Bahasa Indonesia, s.v. "himne."

${ }^{14}$ Roy Sari Milda, Pujangga Hujan: Teori Dan Apresiasi Puisi (Banda Aceh: CBK Digital Publishing, 2019), 12.

\footnotetext{
${ }^{15}$ Johansson, 126.

${ }^{16}$ Milda, 12.

17 Johansson, 126.
} 
dapat dikatakan sebagai nyanyian pujian yang adalah, satu-satunya bentuk musik congregational atau jemaat yang secara saksama dan sistematis dinyanyikan dalam merayakan siklus peristiwa-peristiwa alkitabiah maupun gerejawi yang membentuk landasan iman. Sebagai musik jemaat membutuhkan penerapan disiplin mental dan spiritual yang khas dalam kehidupan kekristenan. ${ }^{18}$

Kontribusi terbesar yang diberikan himne kepada gereja adalah penyempurnaan dari nurani dalam bentuk yang penuh gairah. Jemaat menekankan isi dan berita yang ditampilkan melalui nada dengan perasaan, dan warna dengan bentuk artistik sebagai sebuah seni yang Alkitabiah dan musikal dari umat Allah. Dinyanyikan dengan penuh perhatian dan antusias, membawa seseorang masuk kedalam kebenaran yang nyata dan terang benderang. ${ }^{19}$

\section{Bentuk Himne}

Himne adalah puisi yang ditulis berdasarkan sastra Yunani. Bentuknya berupa rangkaian kata yang disusun secara berbait, setiap bait terdiri dari empat baris dengan jumlah suku kata yang sama dalam setiap baris. Biasanya baitnya bisa lebih dari 8-10, tidak mempunyai kor atau refren. Sama seperti nyanyian rohani yang berbait, bait-bait himne dapat dinyanyikan secara acak, artinya tidak harus dinyanyikan secara berurut dari bait satu dan seterusnya. Bait-bait himne bersifat mandiri meskipun bisa juga dari bait satu hingga bait terakhir ada juga yang tidak boleh dipisahkan waktu dinyanyikan, misalnya himne yang temanya Allah Tri Tunggal. ${ }^{20}$

Musik tidak hanya sekedar suara, dan harmonisasi, namun memiliki bentuk. Pada umumnya nyanyian himne mempunyai sebuah makna yang disampaikan melalui syair yang dinyanyikan. Keindahan dari jenis nyanyian ini terletak pada cara pembawaannya; menyanyikannya membutuhkan penjiwaan, penghayatan, dan dinamika agar makna yang terkandung dalam lagu dapat dirasakan dan dapat disampaikan dengan baik. ${ }^{21}$

Dari sudut ilmu musik, himne digolongkan sebagai community singing yaitu, nyanyian bersama yang dapat dilakukan secara massal. Sifat maupun tujuan nyanyian jemaat adalah menyatukan seluruh umat secara oukumenis dalam ibadah. ${ }^{22}$ Sehingga tercipta kesadaran kesatuan di dalam Kristus sebagai pusat penyembahan.

\section{Ciri Himne}

Ciri nyanyian yang digolongkan sebagai himne adalah: mengekspresikan keesahan Allah, mudah dinyanyikan bersama-sama. Bahasanya sederhana, artinya mudah dipahami dan mudah diingat. Isi tidak bersifat pribadi - seperti mengisahkan pengalaman hidup, sangat individual - bentuk syair teratur, dari bait ke bait tidak berubah-ubah, melodi stabil. Nada terendah dan tinggi dapat dijangkau dinyanyikan oleh seluruh jemaat. ${ }^{23}$

Selanjutnya, dalam studi kesusastraan Barat Klasik, himne adalah salah satu bentuk sastra puisi yang memiliki ciri-ciri umum seperti: adanya penggunaan metrik atau struktur ritme di dalam baris suatu puisi, misalnya ditunjukkan dengan adanya pola keseragaman jumlah suku kata; bentuk strofik yaitu menggunakan melodi lagu yang sama untuk syair bait yang berbeda; dan adanya rima, yaitu pola bunyi akhir (terdengar) atau pola akhiran (tertulis) di setiap baris syairnya. ${ }^{24}$

Dapat disimpulkan bahwa struktur musik, dalam himne memiliki pola yang teratur, memenuhi ketentuan yang memadai, upaya terbentuknya nyanyian jemaat. Dari segi makna merupakan cerminan dari pangajaran Alkitab, yang digubah oleh musisi-musisi dengan teologi yang benar.

\footnotetext{
18 Ibid, 126.

${ }^{19}$ Johansson, 126.

${ }^{20}$ Ibid.

${ }^{21}$ Kevin Maulana Christa, "Persepsi Jemaat Terhadap Musik Iringan Dalam Ibadah Di Gereja Kristen Indonesia (GKI) Sragen,” Jurnal Pendidikan Seni Musik 5, no. 1 (10 Februari 2016):7, http://journal.student.uny.ac.id/ojs/ojs/index.php/musik/article/view/4070.

${ }^{22}$ Rohani Siahaan, "Memahami Nyanyian Jemaat Sebagai Sentral Musik Gereja Apa dan Bagaimana?," Jurnal Jaffray 10, no. 2 (1 Oktober 2012): 158, https://doi.org/10.25278/jj71.v10i2.

${ }^{23}$ Siahaan, 158.

${ }^{24}$ Tandei, 87.
} 


\section{Latar Belakang Lagu Nyawa-Ku Dibrikan Bagimu}

Setiap karya tentu mempunyai latar belakang yang didasari oleh sebuah ide. Seorang seniman biasanya menyimpan pesan yang ingin disampaikan melalui karyanya. ${ }^{25}$ Dan hal yang lumrah apabila ada keinginan untuk mengetahui latar belakang terciptanya sebuah karya yang memiliki nilai keindahan, kemurnian, kepopuleran, apalagi jika ada keistimewaannya.

Pengalaman kehidupan rohani atau pergumulan hidup yang sulit memang seringkali menjadi sumber ide atau ilham untuk menghasilkan sebuah karya, biasanya para musisi atau pekerja seni mengalami hal tersebut. Seperti yang dapat dikemukakan di sini, yaitu Frances Ridley Havergal, seorang perempuan berbakat, yang karyanya menjadi syair nyanyian yang sangat terkenal, sampai sekarang masih terus dinyanyikan pada saat ibadah gereja, terlebih jika ibadah dirangkaikan dengan perjamuan kudus, yaitu: lagu "Nyawa-Ku Dibrikan Bagimu" (NKI 49).

\section{Frances Ridley Havergal}

\section{Puteri Pendeta}

Dilahirkan di Astley, Worchestershire Inggris pada 14 Desember 1836. Bungsu dari empat bersaudara ini merupakan puteri dari William Henry Havergal, seorang pendeta gereja presbiterian di daerah tempat tinggal mereka di Astley. ${ }^{26}$

\section{Pendidikan dan Pertobatan}

Pada usia empat belas tahun saat ia baru mengalami pertobatan, Frances menjalani masa sekolah di Inggris dan mengharuskannya tinggal di asrama. Pengaruh dari perempuan saleh kepala asrama bernama Caroline, ditambah dengan warisan iman yang kuat dari ayahnya, Frances Readly Havergal berhasil menjadi seorang penginjil yang bersemangat memanfaatkan setiap kesempatan untuk bersaksi tentang Yesus. Pada usia dua puluh dua tahun Frances telah menghafal semua Injil, Surat-surat, Wahyu, Mazmur, dan Yesaya. ${ }^{27}$

Kesukaannya merenungkan firman Tuhan memberi inspirasi baginya untuk menulis puisi yang berdasarkan ayat-ayat alkitab dan menjadikannya sebagai syair nyanyian yang banyak menguatkan iman orang percaya dalam mengikut Yesus. ${ }^{28}$ Dengan kedekatan kepada Tuhan memberi dorongan besar bagi dirinya untuk terus berkarya.

\section{Awal sebuah ide}

Selain menulis puisi, Frances tercatat juga sebagai seorang pianis yang sangat berbakat dan solis yang berkomitmen untuk menyanyikan lagu-lagu suci hanya untuk kemuliaan Tuhan ${ }^{29}$ rupanya ia mewarisi bakat musik dari ayahnya.

Untuk memperluas pengetahuannya, Frances pergi belajar di Dusseldrof, Jerman. Dalam satu kesempatan, ia mengunjungi galeri seni di kota itu dan melihat lukisan yang dibuat Sternberg. Lukisan yang diberi nama "Ecco Homo" tersebut menggambarkan Yesus di hadapan Pontius Pilatus, yang diberi mahkota duri itu memuat tulisan, "Ini Aku lakukan untuk kamu, apa yang kamu lakukan untuk aku.?"30 Oleh Frances, tulisan itu menjadi inspirasi untuk menulis syair. Tampaknya ia tidak berpikir panjang, benarkah Yesus mengucapkan kata-kata seperti dalam tulisan tersebut?

Setelah diteliti, ternyata tulisan tersebut tidak memiliki arti apa-apa, selain dari buah pikiran si pelukis. Ayahnya yang mengetahui hal itu, mendorongnya agar tulisan tersebut dibuat menjadi sebuah syair lagu. Lalu ide ini digubah oleh seorang komposer lagu-lagu Gospel terkenal di Amerika, yaitu Philip. P. Bliss, yang kemudian didedikasikan kepada Railroad Chapel Sunday School di Chicago, dan untuk pertama kali dibawakan pada Sunshine for Sunday School tahun $1873 .{ }^{31}$

${ }^{25}$ Karina Anjani, Apa Itu Musik (Tangerang Selatan: Marjin Kiri, 2014), 3.

${ }^{26}$ Wesley L. Duewel, Heroes of the Holy Life: Biographies of Fully Devoted Followers of Christ (USA: Zondervan, 2009), 80.

${ }^{27}$ Duewel, 81.

${ }^{28}$ Duewel, 82 .

${ }^{29}$ Ibid, 82.

${ }^{30}$ Alfred Simanjuntak, Kisah Kidung (Jakarta: Yamuger, 2006), 83

${ }^{31}$ Herwan oroh, "Documents.tips 117 kisah-menarik-lagu-sion," https:/www.slideshare.net/Herwanoroh1/documentstips-117-kisahmenariklagusion, 27. 


\section{Karya Frances Redley Havergal}

Karya-karya Frances terkenal memberi dampak dalam kehidupan orang percaya untuk mengenal kasih Yesus dalam pengorbanan-Nya bagi semua orang. Lewat nyanyian Frances Ridley Havergal mengungkapan suatu pesan yang menguatkan iman setiap pribadi yang mengambil keputusan untuk menginjili dalam pimpinan Tuhan. Sangat jelas bahwa inspirasi menulis berdasarkan pengalaman spiritual dalam pelayanan yang menjadi acuan terciptanya lagu tersebut.

Walaupun kesehatannya tercatat cukup rapuh, namun ia cukup produktif sampai hidupnya berakhir di usia empat puluh tiga tahun. Frances meninggalkan karya sebanyak 50 syair lagu, ${ }^{32}$ tiga di antaranya paling terkenal yaitu: 1) "Aku Memberi Hidupku Untukmu" 2) "Ambil Hidupku dan Biarkan" 3) "Tuhan, Berbicaralah Padaku Bahwa Aku Mungkin Berbicara" 33 Ke tiga lagu ini dinyatakan sebagai nyanyian yang memberi dampak besar dalam kehidupan orang percaya untuk mengenal kasih Yesus dan pengorbanan-Nya. Banyak pula yang mengatakan, bahwa nyanyian-nyanyian karya Havergal tampak mencerminkan penginjilan di mana isi dan pesan lagunya adalah mengajak orang untuk percaya kepada Kristus.

Nyanyian yang berjudul "Nyawa-Ku Diberikan Bagimu" adalah, nyanyian yang sudah sangat dikenal dan terkenal di kalangan jemaat gereja. Namun karena gereja memiliki buku nyanyian yang diterbitkan oleh sinode masing-masing, bisa saja ada perbedaan terutama pada syair, karena penerbit mempunyai versi syair masing-masing meskipun isi dan pesan lagu tetap sama.

Beberapa contoh dapat dikemukakan antara lain: buku Nyanyikan Kidung Baru yang dipakai oleh GKI lagunya berjudul: "Kub'rikan Bagimu Tubuh-Ku, Darah-Ku" (NKB 84) ${ }^{34}$ Dalam buku Kidung Puji-Pujian Kristen yang dipakai di kalangan Persekutuan Gereja-Gereja Tionghoa Indonesia atau PGTI diberi judul: "Nyawa-Ku Diberikan" (KPPK 399) ${ }^{35}$. Pada buku Nyanyian Pujian, judulnya "Kus'rahkan HidupKu Karnamu" (NP 304). ${ }^{36}$ Sedangkan pada buku Paduan Suara Kebenaran judulnya tercatat: "Njawaku Diberikan" (PSK 339). ${ }^{37}$

\section{Philip Paul Bliss}

Philip Paul Bliss, seorang komposer dan penyanyi yang menimba pengalaman bermusik dari pendidikan musik formal. Lahir di wilayah Clearfield Kota Pennsylvania, Utara pada tanggal 9 Juli 1838. Saat berusia sembilan belas tahun, waktu itu musim dingin, untuk pertama kalinya ia masuk sekolah vokal. Kemudian pada kesempatan berikut, ia mengikuti kongres musik di Roma dan New York tahun 1860, sebelum akhirnya ia menjalani pendidikan lanjut di Normal Academy of Music di Geneseo, New York. ${ }^{38}$

Dilahirkan dari keluarga yang hidup di ujung tanduk kemiskinan, tidak membuat Philip Paul Bliss kehilangan kehangatan dan kasih sayang orang tua. Ayahnya Isaac Bliss dan ibunya Lydia Doolitte, senantiasa membangun hubungan keluarga yang penuh cinta kasih yang utuh dan akrab. Sebagai seorang pria, ayahnya Isaac dengan kesederhanaannya melakukan doa keluarga secara teratur dan menghabiskan sebagian besar hidupnya membaca Alkitab dan menyanyikan lagu religius. ${ }^{39}$ Keharmonisan dalam nilai-nilai keluarga Kristen membentuk karakter Philip Paul Bliss, dan memacu dirinya untuk bekerja keras dalam menempuh pendidikan musik.

Setelah dua belas tahun perjalanan komposer Paul P. Bliss menulis lagu, pada salah satu turnya ia bertemu dengan penginjil George L. Moody yang menawarkan sekaligus mendorong dirinya untuk untuk mencurahkan seluruh waktunya untuk menjadi pelayan musik gospel dan upaya penginjilan. ${ }^{40}$

\footnotetext{
${ }^{32}$ Simanjuntak, 83.

${ }^{33}$ Ruth A. Tucker and Walter L. Liefeld, Daughters Of The Church: Women And Ministry From New Testament Times To The Present (America: Zondervan, 2010), 275.

${ }^{34}$ NKB 84 - Kidung," Institut Cristian Worship, diakses 1 Maret 2020, https://Kidung.Co/?Title=nkb84.

${ }^{35}$ KPPK 399 "Nyawa-Ku Diberikan” diakses 1 Maret 2020, https://alkitabappppk230

${ }^{36}$ NP 304“Kus'rahkan Hidupku Karnamu," diakses 1 Maret 2020, https://alkitab.app/np/304.

${ }^{37}$ Ishak Lew, Paduan Suara Kebenaran (Surabaya: Kanada Baru, 1966), 165.

${ }^{38}$ Philip P. Bliss, Biografi Kristiani, diakses 2 Maret 2020, https://biokristi.sabda.org/philip_p_bliss.

${ }^{39}$ James P. Burke, Pioneers of Second Fork (America: AuthorHouse, 2009), 212.

${ }^{40}$ Burke, 214.
} 
Tawaran ini pun diterimanya, dan salah satu karya gubahannya yang terkenal adalah lagu yang digubahnya untuk syair ciptaan Frances Ridley Havergal, berjudul: "Nyawa-Ku Diberikan Bagimu

\section{METODE}

\section{Pengertian Metodologi}

Metodologi menurut Kamus Besar Bahasa Indonesia adalah, ilmu tentang metode atau cara yang digunakan pada suatu sistem kerja yang teratur. ${ }^{41}$ Metodologi dapat juga diartikan sebagai suatu studi penelitian yang digunakan sehingga menghasilkan pengetahuan baru. ${ }^{42}$ Dengan metode musik, penulis akan mengkaji syair lagu "Nyawa-Ku Diberikan Bagimu" NKI 49 melalui Library Research sehingga mendapatkan makna dari hasil penelitian kepustakaan.

\section{Jenis Penelitian}

Penulis dalam hal ini menggunakan jenis penelitian dengan cara kepustakaan atau Library Research. Artinya menggunakan penelitian dengan sumber: buku-buku, jurnal, kamus, Alkitab, dan sumbersumber lainnya, yang berhubungan dengan pokok masalah penulisan karya ilmiah.

\section{Analisis Data}

Analisis data adalah proses mencari dan menyusun secara sistematis data yang diperoleh. Analisis data yang dilakukan dengan, mengorganisasikan data, menjabarkan ke dalam unit-unit, melakukan sintesa, menyusun kedalam pola, memilih mana yang penting dan yang akan dipelajari dan membuat kesimpulan yang dapat diceritakan kepada orang lain. ${ }^{43}$ Analisis data yang dilakukan yaitu:

\section{Reduksi Data}

Pada tahap awal ini penulis melakukan pemilihan, pemfokusan, penyederhanaan, abstraksi dan pentransformasian data mentah dalam catatan-cataan tertulis. Tujuannya adalah untuk melakukan temuan-temuan yang kemuduian menjadi fokus dalam penelitian tersebut.

\section{Display Data}

Tahap ini data yang sudah direduksi kemudian didisplay hingga memberikan pemahaman terhadap data tersebut agar bisa menentukan langkah selanjutnya yang akan dilakukan oleh penulis dalam proses penelitian.

\section{Gambaran Kesimpulan}

Setelah reduksi data terlaksana, maka dilakukan penarikan kesimpulan dari data yang telah ditelitih, dari kesimpulan tersebut dipaparkan penemuan baru dari penelitian yang dilakukan. Namun hasil ini masih bisa ditelitih kembali dan kembali dilakukan reduksi, display data dan kembali akan menghasilkan kesimpulan, begitu seterusnya agar mendapatkan hasil yang maksimal.

\section{Teknik Pengumpulan Data}

Dalam satu penelitian, data harus akurat sehingga penulis dalam hal ini mengumpul data dengan cara Library Research, yaitu penelitian kepustakaan. Pengumpulan data menggunakan buku-buku maupun jurnal, e-book yang mendukung dan menjawab pembahasan dari pokok masalah. Selain itu penelitian kepustakaan juga meneliti isi dari makna syair lagu "Nyawa-Ku Diberikan Bagimu," yang menjadi penjelasan dalam pembahasan.

${ }^{41}$ Kamus Besar Bahasa Indonesia, s.v. "metodologi."

${ }^{42}$ Kris H. Timotius, Pengantar Metodologi Penelitian: Pendekatan Manajemen Pengetahuan untuk Perkembangan Pengetahuan (Yogyakarta: ANDI, 2017), 5. 
HASIL DAN PEMBAHASAN

Memahami Lagu Melalui Makna Syair

Deskripsi Lagu

Judul Lagu : :Nyawa-Ku Diberikan Bagimu" (NKI 49)

Judul Asli : I Gave My Life For Thee (Hymns of the Christian Life No. 71)

Ciptaan : Frances Redley Havergal

Komposer : Philip Paul Bliss

Sumber Syair

Syair lagu "Nyawa-Ku Diberikan Bagimu" bersumber dari tulisan yang terdapat di bawah lukisan karya Sternberg bernama "Ecco Homo." Lukisan tersebut bergambar Yesus bermahkota duri di hadapan Pontius Pilatus; bunyi tulisan tersebut: "Ini Aku lakukan untuk kamu, apa yang kamu lakukan untuk aku?" 44

\section{Ide Terinpirasinya Lagu Nyawa-Ku Diberikan Bagimu}

Penulisan syair lagu "Nyawa-Ku Diberikan Bagimu" pada setiap frasa merupakan kutipan ayat-ayat Alkitab, seperti: Nyawa-Ku diberikan bagimu (Gal. 2:20), darah-Ku tercurah (1 Ptr. 1:19), kau dapat tebusan (Ef. 1:7), dari mati bangkitlah (Ef. 2:1), nyawa-Ku diberikan bagimu (Tit. 2:14), apa kau beri pada-Ku? (Yoh. 21:15-17). Rumah-Ku ditinggal (1 Tim. 1:15; Yoh 17:5), dan takhta kemuliaan (Mat. 25:31). Ku masuk dunia gelap (Flp. 2:7; Yoh. 17:24), bertandang sendirian (Yoh. 16:22), Kutinggalkan s'mua bagimu (Yoh. 1:10-11; 2 Kor. 8:9), apa kau b'ri pada-Ku? (1 Ptr. 4:2). ${ }^{45}$

$\mathrm{Ku}$ disengsarakan (Yes. 53:5), dengan amat keji (Mat. 26:39), 'gar kau dilepaskan (Rm. 5:9), dari celaka dan pedih (Luk. 22:44), Ku disengsarakan bagimu (1 Pet. 2:21-24), apa kau b'ri pada-Ku (Rm. 8:17-18). Ku bawakan dikau (Yoh. 4:10, 14), dari rumah-Ku t'rang (Yoh. 3:13), s'lamat yang percuma (Why. 21:6; Rm. 3:24), Ku memberi berkat kepadamu (Mzm. 68:18-19), apa kau b'ri pada-Ku (Rm. 12:1). ${ }^{46}$

\section{Makna Syair Lagu "Nyawa-Ku Diberikan Bagimu"}

Secara filosofis, pemaknaan syair musik pada masa tradisi Gereja Khatolik Roma di Italia berorientasi pada filosofi kristiani yang dikaitkan antara teks dan lagu. Para komponis sangat memperhatikan spirit dan mood sebuah teks dalam kerangka nyanyian spiritualitas kristiani. ${ }^{47}$ Syair nyanyian menjadi sarana pengajaran yang bermakna, jika ditinjau berdasarkan pengajaran Alkitab dan melihat sejarah musik. Alkitab mencatat bahwa nyanyian merupakan suatu ungkapan syukur umat kepada Allah atas kemenangan-kemenangan yang Tuhan kerjakan. Hal ini terlihat dalam Keluaran 15:1, "Baiklah aku menyanyi bagi Tuhan, sebab Ia tinggi luhur, kuda dan penunggangnya dilemparkan-Nya ke dalam laut.” Allah sendiri yang menghancurkan musuh-musuh-Nya dan membawa umat Israel keluar dari perbudakan dosa, yang melukiskan kemenangan Kristus atas kuasa dosa dan maut. ${ }^{48}$ Diungkapkan pada peristiwa masa lampau, dilihat, dan berlaku sampai sekarang nyanyian dinyanyikan sebagai ungkapan syukur kepada Allah dalam setiap peristiwa kehidupan dan setiap generasi dapat mengalaminya. ${ }^{49}$

\footnotetext{
${ }^{44}$ Simanjuntak, 83.

${ }^{45}$ Charles J. Doe, The Hymns of Frances Ridley Havergal (Mineapolis: Curiosmith, 2017), 36.

${ }^{46}$ Doe, 37.

${ }^{47}$ Supriyadi Supriyadi, "Nilai Estetis Musik Dalam Rentang Sejarah Musik Barat," Tonika: Jurnal Penelitian Dan Pengkajian Seni 2, no. 1 (29 Mei 2019): 8, https://doi.org/10.37368/tonika.v2i1.39.

${ }^{48}$ F. L. Bakker, Sejarah Kerajaan Allah 1: Perjanjian Lama (Jakarta: BPK Gunung Mulia, 2007), 288.

${ }^{49}$ W. S. Lasor, D. A. Hubbard, dan W. F. Bush, Pengantar Perjanjian Lama 1 (Jakarta: BPK Gunung Mulia, 2008).
} 
Dikisahkan dalam Perjanjian Baru nyanyian Maria, berdasarkan Lukas 1:46-55 memuji perbuatan-perbuatan Allah yang besar karena Anak-Nya yang di kandungnya. ${ }^{50}$ Jiwanya memuji Allah dengan ucapan syukur atas rahmat yang diberikan kepada dirinya. Nyanyian himne yang dicetak ulang dari waktu ke waktu dalam gerakan penginjilan memberitakan dasar iman Kristen. Berpotensi untuk menyatakan keberadaan Kristus sang penyelamat, kasih Allah dalam Kristus, kuasa penyelamatan Kristus, perlindungan penyembuhan dalam Kristus dan sukacita penebusan dalam Kristus. ${ }^{51}$ Berkaca dari hal di atas, pemaknaan nyanyian dalam kehidupan orang percaya mencapai persekutuan yang intim dengan Tuhan, selayaknya terlebih dahulu memahami syair lagu dengan benar.

\section{Bait 1}

\section{Makna Lagu}

Nyawa-Ku dib'rikan darah ku tercurah, Kau dapat tebusan dari mati bangkitlah, Nyawa-Ku dib'rikan bagimu apa kau b'ri pada-Ku?Nyawa-Ku dib'rikan bagimu apa kau b'ri pada-Ku?Bait pertama menggambarkan Yesus yang memberi nyawa-Nya menanggung beban berat untuk memberi tebusan bagi semua orang berdosa. Harga yang harus dibayar adalah kematian dan kemenangan atas kematian, yaitu kebangkitan. Ini mengajarkan kuasa dosa yang dahsyat, sehingga Allah Bapa merelakan Anak-Nya yang sangat Ia kasihi memikul beban dosa tanpa pertolongan dan perlindungan. ${ }^{52}$

Pencipta lagu "Nyawa-Ku Diberikan Bagimu," menyampaikan pesan bahwa tidak ada keselamatan di luar Yesus. Setiap orang percaya harus menyadari bahwa pengorbanan Yesus merupakan ketidakberdayaan manusia untuk menyelamatkan dirinya dari kuasa dosa. Pengorbanan Tuhan Yesus adalah jaminan penyelamatan yang mahal harganya. Selayaknyalah sebagai orang percaya meresponi pengorbanan tersebut dengan penuh tanggung jawab. $^{53}$

\section{Bait 2}

Rumah-Ku ditinggal dan takhta kemuliaan, Ku masuk dunia g'lap bertandang sendirian Kutinggalkan s'mua bagimu apa kau b'ri pada-Ku? Kutinggalkan s'mua bagimu apa kau b'ri pada-Ku? Gambaran rumah di surga sama dengan tubuh kemuliaan-Nya. ${ }^{54}$ Yesus dari takhta kemuliaan-Nya turun ke dalam dunia yang penuh dosa demi menyelamatkan umat manusia. Kristus Yesus, "yang walaupun dalam rupa Allah, tidak menganggap kesetaraan dengan Allah itu sebagai milik yang harus dipertahankan, melainkan telah mengosongkan diriNya sendiri, dan mengambil rupa seorang hamba, menjadi sama dengan manusia" (Flp. 2:6-7). Dalam keadaan sebagai manusia, Ia telah merendahkan diri-Nya dan taat sampai mati, bahkan sampai mati di kayu salib." 55

\section{Bait 3}

$\mathrm{Ku}$ disengsarakan dengan amat keji 'gar kau dilepaskan dari celaka pedih $\mathrm{Ku}$ disengsarakan bagimu apa kau b'ri pada-Ku? Ku disengsarakan bagimu apa kau b'ri pada$\mathrm{Ku}$ ?Yesus menanggung kesengsaraan yang amat keji karena dosa manusia, aniaya, celaan,

\footnotetext{
${ }^{50}$ David J. Bosch, Transformasi Misi Kristen (Jakarta: BPK Gunung Mulia, 2006), 167.

${ }^{51}$ Richard J. Mouw, Wonderful Words of Life: Hymns in American Protestant History and Theology (America: Wm. B. Eerdmans Publishing, 2004), 7.

52 Aldorio Flavius Lele dan Robi Panggarra, "Makna Tujuh Ungkapan Yesus Di Salib Bagi Orang Percaya," Jurnal Jaffray 13, no. 2 (29 September 2015): 267, https://doi.org/10.25278/jj71.v13i2.181.

${ }^{53}$ Nasokhili Giawa, "Serving Others: Keteladanan Pelayanan Yesus Kristus Berdasarkan Yohanes 13," Integritas: Jurnal Teologi 1, no. 1 (27 Juni 2019): 62, http://journal.sttjaffrayjakarta.ac.id/index.php/ji/article/view/9.

${ }^{54}$ Daniel Ronda, “Doktrin Tentang Surga: Relevansinya Bagi Tugas Misi Sedunia,” Jurnal Jaffray 12, no. 2 (2 Oktober 2014): 205, https://doi.org/10.25278/jj71.v12i2.14.

${ }^{55}$ Hendra G. Mulia, "Sejarah dan Tinjauan Kritis tentang Teori Kenosis," Jurnal Pelita Zaman 7, no. 1 (1992): 1, https://alkitab.sabda.org/resource.php?topic=303\&res=jpz.
} 
difitnah, menjelaskan kehilangan tempat dalam persekutuan Yahudi. ${ }^{56}$ Penderitaan ini bukan tanpa makna, melainkan berdaya penebusan, mendatangkan kehidupan serta memberi keselamatan bagi semua orang yang masih hidup dalam dosa. ${ }^{57}$ Kehadiran-Nya di bumi menyatakan dan melaksanakan kehendak Bapa, yaitu mengerjakan keselamatan bagi orang berdosa, melalui kehidupan pelayanan, kesengsaraan, penyaliban dan kematian di kayu salib. Selama kehidupan Yesus di dunia berkaitan langsung dengan keselamatan manusia. ${ }^{58}$

Misi penyelamatan Allah bagi manusia melalui pengorbanan Kristus di kayu salib merupakan pusat dari penyataan Allah tentang diri-Nya kepada manusia. ${ }^{59}$ Bahwasannya Tuhan tidak akan pernah meninggalkan umat-Nya. Kesengsaraan Yesus bukanlah kekalahan Juruselamat, tetapi merupakan kemenangan-Nya terhadap rasa sakit dan penderitaan, yang menghasilkan kuasa kesembuhan bagi umat yang dikasihi-Nya.

\section{Bait 4}

$\mathrm{Ku}$ bawakan dikau dari rumah-Ku t'rangS'lamat yang percuma ampun dan pengasihan $\mathrm{Ku}$ memb'ri berkat kepadamu apa kau b'ri pada-Ku? Ku memb'ri berkat kepadamu apa kau b'ri pada-Ku? Alkitab diselubungi oleh kiasan tentang terang secara literal dan secara kiasan. Dalam Alkitab terang adalah ciptaan pertama (Kej. 1:3-4). ${ }^{60}$ Terang merupakan kebutuhan dalam kehidupan manusia. Yesus dari takhta kemuliaan-Nya membawa terang ke dalam kehidupan manusia, dengan maksud memberi keselamatan secara cuma-cuma. Dalam Perjanjian Baru mengisahkan bagaimana suatu pelepasan dari perbudakan dosa berdasarkan kehidupan Kristus, darah yang tercurah di kayu salib merupakan kekuatan Allah yang menyelamatkan. ${ }^{61}$

Pengorbanan yang penuh pengasihan Ia berikan kepada manusia. Terang adalah sinar pelita yang menerangi orang yang ada dalam gelap, dan Kristus sumber terang sejati bagi orang percaya (Yoh. 8:12) ${ }^{62}$ Yohanes menyingkapkan suatu yang lebih dalam mengenai Yesus sebagai terang, saat kedatangan-Nya kembali bukan hanya memberi cahaya dan berada di tengah-tengah orang Yahudi. Melainkan wujud yang nyata dapat berbicara, berjalan dan mengajar langsung kepada manusia. ${ }^{63}$

Kehadiran Yesus sebagai terang kehidupan memberi suatu pengharapan yang pasti bagi orang semua orang yang percaya kepada-Nya. "Percayalah kepada terang itu, selama terang itu ada padamu, supaya kamu menjadi anak-anak terang." (Yoh. 12:36). Cahaya pimpinan dari Allah sendiri yang mengarahkan langsung ke dalam rumah Bapa melalui Yesus. ${ }^{64}$

\section{Pokok Pikiran Lagu dalam Syair "Apa Kau B'ri Pada-Ku”}

Sebagaimana kategori nyanyian rohani atau nyanyian injili yang terdiri dari beberapa bait dan memiliki kor atau refren, dapat dikatakan bahwa nyanyian "Nyawa-Ku Diberikan Bagimu"

${ }^{56}$ Adolf Bastian Simamora, "Perspektif Biblikal Tentang Agama Dan Kekerasan Dalam Peristiwa Penyaliban Yesus," Voice Of Wesley: Jurnal Ilmiah Musik Dan Agama 1, no. 2 (2018): 9, https://doi.org/10.36972/jvow.V1i2.11.9.

${ }^{57}$ Alfonsus Ara, “Upaya Mencari Gambaran Yesus Yang Bercorak Ke-Asia-An,” Logos 8, no. 1 (Januari 2011): 51, https://www.neliti.comnone.

58 Peniel C. D. Maiaweng, "Inkarnasi:Realitas Kemanusiaan Yesus," Jurnal Jaffray 13, no. 1 (20 Maret 2015): 97, https://doi.org/10.25278/jj71.v13i1.114.

${ }^{59}$ Hana Ruben Dannari, "Kajian Teologi Tentang Penderitaan Yesus Sebagai Anak Daud," Jurnal Osf Preprints, (26 Februari 2020): 3, https://doi.org/10.31219/osf.io/x8t6c.

${ }^{60}$ Leland Ryken, James Wilhoit, dan Tremper Longman III, Kamus Gambaran Alkitab (Surabaya: Momentum, 2011), 1119.

${ }^{61}$ Ryken, Wilhoit, dan Longman III, 973.

${ }^{62}$ Bambang Wiku Hermanto dan Yohanes Enci Patandean, "Tema-Tema Theologis Khotbah Yesus Di Bukit Dalam Injil Matius 5:1-7:29," Evangelikal Jurnal Teologi Injil dan Pembinaan Warga Jemaat 3, no. 2 (Juli 2019): 128, https://journal.sttsimpson.ac.id/index.php/ejti/article/view/140.

${ }^{63}$ Nepho Laoly, "Yesus Dalam Targum Dan Gulungan Laut Mati,” Pneustos: Jurnal Teologi Pantekosta 1, no. 1 (30 Juni 2018): 36, http://sttpantekostasumutaceh.ac.id/ejournal/index.php/pneustos/article/view/3.

${ }^{64}$ Laoly, 37. 
dapat dikategorikan sebagai nyanyian rohani, karena pada setiap bait syair terdapat pengulangan kata yang sama yaitu, Apa Kau B'ri pada-Ku. Pokok pikiran dalam setiap bait terdapat dalam refrein. ${ }^{65}$ Artinya ialah, pengulangan kata pada frase terakhir dari setiap bait menjadi pokok pikiran atau inti dari keseluruhan lagu; meskipun dari bentuk penulisan syairnya bukan termasuk kategori nyanyian rohani yang terdiri dari bait dan koor. Apa Kau B'rikan Pada-Ku, merupakan ungkapan pertanyaan yang sesungguhnya jawabannya sudah ada pada pernyataan setiap frasa syair dari ke empat bait lagu.Bait satu, dari lima frasa pernyataan menggambarkan pengorbanan Yesus. Bait kedua, dari lima frasa pernyataan menggambarkan pengorbanan itu membuat-Nya meninggalkan takhta Bapa. Bait ketiga, dari lima frasa pernyataan menggambarkan pengorbanan itu adalah kesengsaraan Kristus.Bait keempat, dari lima frasa pernyataan menggambarkan pengorbanan Yesus menjadi terang keselamatan bagi umat manusia.

Setelah mencermati uraian setiap frasa pernyataan dalam syair dan maknanya pada setiap bait lagu, maka jelaslah pokok pikiran atau pesan dalam lagu "Nyawa-Ku Diberikan Bagimu" hanya merupakan pengembangan dari sebuah ide seorang Frances Ridley Havergal saat melihat lukisan Yesus bermahkota duri. Ide yang menggambarkan 'dialog' imajinasi Frances atas derita Yesus, jadi bukan 'tuntutan' Yesus secara langsung kepada manusia.

Apa Kau Beri Padaku merupakan suatu pengembangan ide yang pencipta lagu dari suatu tulisan di bawah lukisan Yesus bermahkota duri di hadapan Pontius Pilatus. "Ini Aku lakukan untuk kamu, apa yang kamu lakukan untuk aku?" Frasa ini diaplikasikan menjadi suatu syair lagu yang seolah-olah Yesus meminta balasan dari orang percaya atas penebusan yang dilakukan.

Makna dari frasa Apa Kau Beri Padaku yang menjadi bagian penting dalam lagu ini, mendorong orang percaya mengalpikasikan pengorbanan Yesus dalam mengarahkan kehidupannya untuk menjadi pribadi yang memuliakan Allah. Orang percaya tidak dituntut timbal balik dari karya Kristus, namun responsif manusia menerima pendamaian atau pengorbanan itu dilakukan dalam kehidupan sesama manusia. ${ }^{66}$

Pada nas Markus 8:31 terdapat frasa yang berhubungan dengan pendamaian, Yesus menanggung banyak penderitaan, yang merujuk pada totalitas penderitaan Yesus menuju salib bagi banyak orang. Totalitas itu salah satunya terlihat dari cara Yesus menjelaskan diri-Nya sebagai 'anak manusia' sebuah ungkapan posisi terendah dan terdalam sebagai hamba-Nya. ${ }^{67}$ Hal terendah Yesus lakukan mengarahkan seluruh hidup orang percaya kepada suatu kehidupan yang memuliakan Allah dalam menerima pengampunan, kehidupan yang penuh pengharapan sekalipun dalam penderitaan.

Yesus lebih dari sekedar dianiaya oleh karena kebenaran, Tuhan Yesus sendiri bahkan dibunuh dan nyawa-Nya menjadi tebusan bagi manusia. Hal yang paling esensial di sini adalah, oleh karena darah Kristus orang percaya tidak hanya memiliki hak istimewa yang Yesus telah berikan, tetapi juga dapat masuk ke hadirat Allah. ${ }^{68}$ Menikmati persekutuan dengan Allah, sehingga tidak ada lagi orang percaya membakar korban penghapus dosa oleh karena nyawa Yesus cukup untuk penebusan bagi manusia.

65 Siahaan, 160.

${ }^{66}$ Wagelman Purba, "Karya Penyelamatan Yesus Kristus Dilakukan Dalam Status Kerendahan Matius 1:21 Dan Maknanya Bagi Gereja Masa Kini,” Jurnal Pendidikan Religius 1, no. 1 (April 2019): 25, https://jurnal.darmaagung.ac.id/index.php/jurnalreligi/article/view/169.

${ }^{67}$ Sonny Zaluchu, "Penderitaan Kristus Sebagai Wujud Solidaritas Allah Kepada Manusia," Dunamis: Jurnal Penelitian Teologi Dan Pendidikan Kristiani 2, no. 1 (4 November 2017): 68, https://doi.org/10.30648/dun.v2i1.129.

${ }^{68}$ Tison Jermia Djadi, "Pengajaran Tentang Ibadah Berdasarkan Surat Ibrani 10:19-25 Dan Implimentasinya Dalam Kehidupanorang Percaya Pada Masa Kin,” Jurnal Jaffray 11, no. 1 (2 September 2020): 44, https://www.academia.edu/7827029/jurnal_Tison2.44. 
Frasa "apa kau beri pada-Ku?" merupakan pandangan yang keliru jika dikatakan adalah perkataan Yesus, dibandingkan dengan pengajaran firman Tuhan sekalipun menjadi bagian penting dalam lagu. Yesus tidak pernah menuntut atas pengorbanan-Nya di kayu salib berdasarkan Efesus 1:20 "dan oleh Dialah, Ia memperdamaikan segala sesuatu dengan diriNya, baik yang ada di bumi, maupun yang ada di sorga, sesudah Ia mengadakan pendamaian oleh darah salib Kristus." Kehadiran Yesus datang untuk mendamaikan bukan untuk memberi beban baru bagi manusia untuk selamat.

Diterangkan dalam Efesus 2:16-17 kehadiran Yesus ke dalam dunia "untuk memperdamaikan keduanya, di dalam satu tubuh, dengan Allah oleh salib, dengan melenyapkan perseteruan melalui salib itu. Ia datang dan memberitakan damai sejahtera kepada kamu yang "jauh" dan damai sejahtera kepada mereka yang "dekat". Perseteruan Allah dengan manusia telah didamaikan oleh Yesus agar manusia dapat bersekutu dengan Tuhan.

Roma 5:10 Ketika manusia menjadi seteru Allah, Kristus mati demi pendamaian tersebut. Henry menjelaskan dampak pendamaian berdasarkan Roma 5:10 Dosa diampuni, orang berdosa diterima sebagai orang benar, perselisihan didamaikan, permusuhan disingkirkan, kejahatan diakhiri, dan kebenaran kekal di bawah masuk. Paulus menyebut pendamaian itu oleh salib dan hasil dari pendamaian itu adalah jalan masuk kepada Bapa dalam satu Roh (Ef. $2: 18){ }^{69}$

Pendamaian adalah suatu realita yang dilakukan Yesus sendiri. Manusia diperdamaikan itu sudah dikerjakan, entah manusia menerima atau tidak, namun yang pasti Allah sendiri didamaikan dengan manusia melalui kematian Kristus. ${ }^{70}$ Hal yang paling penting untuk manusia lakukan adalah, melakukan kebaikan terhadap sesama, karena tidak mungkin dapat membalas kebaikan Tuhan dengan sempurna.

Dalam Kristus Allah menerima manusia berdosa dan dengan demikian Allah meniadakan dosa, tetapi karya Allah itu menjadi efektif bagi manusia apabila diamini dengan iman. ${ }^{71}$ Menjadi gaya hidup orang percaya setelah bertemu yang telah bertemu dengan Yesus. Artinya, segala sesuatu yang dikerjakan orang percaya bukan karena membalas kebaikan Allah, melainkan bukti dari iman yang bersyukur menerima kasih karunia Allah, yang olehnya orang percaya diselamatkan (Ef. 2:5). "A2 "Apa kau beri pada-Ku" menjadi sebuah dorongan bagi orang percaya untuk membuktikan imannya sungguh, setelah bertemu dengan Yesus kepada sesama.

Makna kasih karunia Allah bagi kehidupan orang percaya, menghadirkan Allah melalui Yesus Kristus ke dalam dunia, mati untuk menyelamatkan manusia, Ia bangkit dari kematian memberi kemenangan bagi orang percaya dan menyediakan tempat bagi yang percaya kepadaNya. ${ }^{73}$ Kasih karunia Allah melepaskan kehidupan manusia dari kuasa kutuk dosa yang menjadi penghalang manusia datang kepada Allah. Kasih karunia Allah itu dianugerahkan kepada manusia secara cuma-cuma dan tidak perlu dibalas.

Dapat disimpulkan, bahwa frasa "apa kau beri padaku" bukanlah perkataan Yesus melainkan ide penulis untuk mendorong orang percaya membuktikan imannya kepada sesama,

${ }^{69}$ Dwiati Yulianingsih dan David Eko Setiawan, "Signifikansi Salib Bagi Kehidupan Manusia dalam Teologi Paulus," Jurnal Teologi Sistematika Dan Praktika 2, no. 2 (Desember 2019): 242, http://www.stt-tawangmangu.ac.id/e-journal/index.php/fidei; Harun Hadiwijono, Iman Kristen (Jakarta: BPK Gunung Mulia, 1995), 346.

${ }^{70}$ Purba, 24.

${ }^{71}$ Dessy Handayani, “Tinjauan Teologis Konsep Iman dan Perbuatan Bagi Keselamatan,” Jurnal Teologi dan Pelayanan Kristiani 4, no. 1 (November 2017): 100, http://www.stttorsina.ac.id/jurnal/index.php/epigraphe.

${ }^{72}$ Hari Sulastio, "Keselamatan Karena Kasih Karunia Menurut Efesus 2:1-10,” Antusias: Jurnal Teologi dan Pelayanan 6, no. 1 (Juni 2020): 74, https://sttintheos.ac.id/e-journal/index.php/antusias.

${ }^{73}$ Rose Melly Merang dan Robi Panggarra, "Makna Kata Kharis Berdasarkan Surat Efesus 2:8 Dan Implementasinya Dalam Kehidupan Orang Percaya Masa Kini,” Jurnal Jaffray 10, no. 2 (1 Oktober 2012): 70, https://doi.org/10.25278/jj71.v10i2.54. 
oleh karena kasih karunia Allah dianugerahkan kepada manusia secara cuma-cuma. Kehadiran Yesus memberi kehidupan, kelepasan dari dosa bagi mereka yang percaya kepada-Nya. Kasih karunia Allah melalui Yesus, yang diberikan kepada orang percaya oleh Roh Kudus, memberi kemurahan hati, pengampunan, dan keinginan untuk melakukan kehendak Allah (Yoh. 3:16; 1 Kor. $15: 10){ }^{74}$

\section{Implikasi Lagu}

Setiap orang percaya dianugerahkan Tuhan untuk menikmati kasih karunia-Nya. Keteladanan hidup di bawah kuasa firman-Nya menjadi dasar iman bagi umat yang percaya. Lagu "Nyawa-Ku Diberikan Bagimu" NKI 49 adalah lagu yang sudah lama dikenal dengan makna syair yang sangat memberkati, meskipun memiliki kelemahan tersendiri dalam penulisan syair, lagu ini tetap mengacu kepada kepribadian Yesus yang menyelamatkan manusia dari belenggu dosa. Dalam peribadatan Gereja Kemah Injil Indonesia, lagu "Nyawa-Ku Diberikan Bagimu NKI 49" hingga saat ini masih digunakan sebagai nyanyian, terutama pada ibadah perjamuan kudus. Biasanya dinyanyikan sebagai lagu penghantar pelaksanaan perjamuan.

Pengenalan akan Kristus lewat nyanyian menjadi salah satu sarana penting dalam pemberitaaan Injil. Dengan demikian jelaslah, bahwa nyanyian "Nyawaku Diberikan Bagimu" adalah gambaran kehidupan orang percaya yang sangat diberkati, dan kehidupan yang diberkati ini diperlihatkan dengan cara:

\section{Mengucap Syukur}

Dari sebuah ide yang menginspirasi lalu dikembangkan menjadi syair lagu atas dasar firman Tuhan, menuntun orang percaya mengakui kedaulatan Tuhan yang memegang kehidupan, kepada keselamatan yang kekal. Nyanyian menjadi bagian ungkapan syukur kepada Allah atas karya penyelamatan yang dikerjakan di kayu salib dengan harga yang mahal. Dalam 1 Tesalonika 5:18 dikatakan: "Mengucap syukurlah dalam segala hal, sebab itulah yang dikehendaki Allah di dalam Kristus Yesus bagi kamu." Sebuah kerinduan yang diinginkan Tuhan dalam hidup ini adalah rasa syukur yang menjadi bagian penting dalam kehidupan orang percaya.

Nyanyian "Nyawa-Ku Diberikan Bagimu" mengajarkan kepada orang percaya, mengucap syukur menjadi bagian penting dalam pertumbuhan iman atas karya penebusan Kristus di kayu salib, demi pendamaian Allah dengan manusia. Menjadikan orang percaya tetap kuat di dalam Tuhan.

"Syukur kepada Allah, yang telah memberikan kemenangan kepada kita, kemenangan oleh Tuhan kita Yesus Kristus" (1 Kor. 15:57). Kemenangan yang sudah diperoleh Yesus Kristus akan dinyatakan kelak bagi yang percaya kepada-Nya, maka kini dan di sini kehidupan ditentukan oleh kemenangan itu. Hidup dan mati telah berada dalam pengharapan yang sejati. ${ }^{75}$ Hidup dengan bersyukur menuntun orang percaya kepada pengenalan akan Yesus. Mengucap syukur kepada Tuhan merupakan tindakan kesaksian tentang Allah yang hidup dan sumber kehidupan. ${ }^{76}$

Mengucap syukur adalah gambaran manusia yang tidak berdaya atas kuasa dosa yang dahsyat, sehingga Allah Bapa mengaruniakan Anak-Nya Yesus Kristus menjadi tebusan, disengsarakan menanggung semuanya untuk pelepasan dari perbudakan kuasa dosa. Penebusan tersebut menjadikan manusia dapat menikmati Anugerah Allah.

Mengucap syukur, tanggapan langsung dari manusia atas anugerah Tuhan, dalam keselamatan melalui Putera-Nya Yesus Kristus sehingga orang percaya memuji dan memuliakan keluhuran Allah. ${ }^{77}$ Karya Kristus di kayu salib menjadi bagian penting dalam

\footnotetext{
${ }^{74}$ Merang dan Panggarra, 71.

${ }^{75}$ Gerrit Cornelis van Niftrik, Dogmatika Masa Kini (Jakarta: BPK Gunung Mulia, 1978), 532.

${ }^{76}$ Sondakh, ed. Firman Hidup 36, (Jakarta: BPK Gunung Mulia, 2009), 59.

${ }^{77}$ Greria Obor, Iman Katolik: Buku Informasi dan Referensi (Yogyakarta: Kanisius, 1996), 198.
} 
hidup orang percaya untuk mengakui bahwa penyelamatan cukup untuk satu kali bagi yang percaya kepada-Nya.

\section{Hidup Dalam Persekutuan}

Kedatangan Kristus ke dalam dunia, menyatukan semua orang melalui kasih karunia yang membangun kehidupan kekal melalui karya penebusan. Di dalam Kisah Para Rasul 2:4147, diberitakan bahwa jemaat yang mula-mula mengalami pertumbuhan yang sangat signifikan. Mereka memiliki pola hidup yang sangat luar biasa: mereka bertekun dalam pengajaran rasulrasul, dalam persekutuan, mereka berkumpul untuk beribadah, berdoa dan memecahkan roti. ${ }^{78}$

Kehidupan dalam persekutuan menyatukan hubungan satu dengan yang lain dalam tujuan memuji dan memuliakan Tuhan. Melihat dari maksud nyanyian "Nyawa-Ku Diberikan Bagimu" merupakan gerakan untuk penginjilan, artinya setiap orang percaya harus hidup dalam kasih Kristus yang telah menyatukan melalui penebusan.

Kehadiran Yesus Kristus ke dalam dunia memisahkan manusia dari perbudakan dosa bagi yang percaya kepada-Nya melalui penderitaan, kesengsaraan, mati dan bangkit dengan tujuan membangun hubungan Allah dengan manusia yang telah rusak oleh karena dosa. Harga yang mahal dikerjakan Yesus Kristus dalam fase kehidupan manusia dipersatukan melalui persekutuan sehingga imannya dapat bertumbuh melalui doa, dan pengalaman kesaksian yang dialami.

\section{Menjadi Saksi Kristus}

Amanat Agung Yesus Kristus melalui nyanyian "Nyawa-Ku Diberikan Bagimu” dimulai dari frasa-frasa setiap bait yang menuntun kepada pengenalan akan Kristus yang telah berkorban bagi keselamatan manusia. Selayaknya orang percaya memiliki kesiapan hati untuk meresponi panggilan penginjilan untuk kabar keselamatan bagi orang yang belum percaya.

Memaknai nyanyian "Nyawa-Ku Diberikan Bagimu” ke dalam kehidupan umat saat ini, menyegarkan iman, membangkitkan semangat penginjilan untuk menjalankan amanat Agung Yesus Kristus yang telah berkorban untuk keselamatan manusia. Yesus meninggalkan semua yang dimiliki untuk melaksanakan suatu perintah yang diberikan oleh Bapa, menjadi teladan bagi orang percaya, memiliki kesiapan hati untuk meninggalkan apapun untuk pemberitaan Injil.

Pemberitaan Injil harus menjadi gaya hidup orang percaya selama di dunia, sama dengan gaya hidup di dalam Kerajaan Allah, yaitu hidup dalam pemerintahan Allah dan kebenaran Allah. Menjaga hati, pikiran, sikap, tindakan, perkataan, perbuatan, yang semuanya itu sama dengan gaya hidup Tuhan Yesus selama Ia masih di dunia. Hidup sama seperti Tuhan Yesus adalah harga mati yang tidak bisa ditawar untuk menjadi warga Kerajaan Allah, sebab cara hidup seperti Tuhan Yesus itulah yang dikehendaki oleh Allah Bapa di sorga. ${ }^{79}$

\section{Menghasilkan Buah}

Tindakan dalam pemberitaan harus dapat menghasilakan buah, dengan bersandar penuh kepada kuasa Roh Kudus dalam menyampaikan injil. Ada harga yang harus dibayar dalam pekabaran Injil (Yoh. 15:16). Bukan kamu yang memilih Aku, tetapi Akulah yang memilih kamu. Dan Aku telah menetapkan kamu pergi dan menghasilkan buah dan buahmu itu tetap, supaya apa yang kamu minta kepada Bapa dalam nama-Ku, diberikan-Nya kepadamu. Pemilihan Tuhan bagi orang percaya merupakan suatu tindakan yang telah ditetapkan Allah

${ }^{78}$ Rahmat Hasudungan Nainggolan, "Pengaruh Cara Hidup Jemaat Mula-Mula Berdasarkan Kisah Para Rasul 2:41-47 Dan Relevansinya Pada Masa Kini," Pneustos: Jurnal Teologi Pantekosta 1, no. 1 (30 Juni 2018): 92, http://sttpantekostasumutaceh.ac.id/e-journal/index.php/pneustos/article/view/8.

${ }^{79}$ Djuwansah Suhendro P. Stephanus, "Mengajarkan Penginjilan Sebagai Gaya Hidup Orang Percaya," Redominate: Jurnal Teologi Dan Pendidikan Kristiani 1, no. 1 (31 Desember 2019): 15, https://sttkerussoindonesia.ac.id/e-journal/index.php/redominate/article/view/2 
bagi setiap orang untuk pekabaran Injil sehingga orang lain pun dapat masuk dalam kerajaan Allah.

Peranan Roh Kudus dalam kehidupan orang percaya untuk memuji dan memuliakan Tuhan, menjadi bagian penting dalam pemberitaan Injil. Selain memperlengkapi orang percaya Roh Kudus memberikan karunia, untuk menghasilkan berbuah tetap di dalam Tuhan. ${ }^{80}$ Roh Kudus membuat orang percaya menghasilkan buah-buah kemenangan yang mengarahkan kepada kunci bersaksi yang efektif. 81 "Nyawa-Ku Diberikan Bagimu" merupakan seruan untuk umat Tuhan dalam memperingati akan pengorbanan Tuhan di kayu salib, sebagai warga kerajaan Allah.

Dalam lingkungan organisai gerejapun harus menghasilkan buah. Gereja harus berkarya untuk dunia dan berbuah untuk dunia. Dengan demikian gereja adalah organisasi yang hidup dan dinamis, dikepalai oleh Yesus Kristus sendiri, harus mengalami pertumbuhan dan menghasilkan buah, sebab tujuan gereja selaku ekklesia adalah mewartakan Kerajaan Allah. ${ }^{82}$

Pengorbanan Yesus bagi semua orang memberikan waktu dan hidup-Nya yang berharga untuk penebusan yang sempurna. Melalui nyanyian "Nyawa-Ku Diberikan Bagimu", menjadi suatu acuan yang penting untuk pekabaran Injil, di mana Yesus telah menjadi teladan dalam pekabaran Injil. Dengan demikian, lewat nyanyianpun dapat memberitakan Injil dan mengaplikasikannya dalam kehidupan beriman setiap hari.

\section{KESIMPULAN}

Setelah menyelesaikan seluruh pembahasan yang berkaitan dengan nyanyian "Nyawa-Ku Diberikan Bagimu" NKI 49, mulai dari latar belakang masalah, beberapa pengertian dan penjelasan, metodologi yang digunakan, masih perlu diperdalam lagi, maka penulis memperoleh kesimpulan sebagai berikut:

Pertama, Nyanyian "Nyawa-Ku Diberikan Bagimu” NKI 49, merupakan karya Frances Redley Havergal, yang musiknya digubah oleh komposer Philip Paul Bliss. Ide penulisan syairnya terinspirasi dari sebuah lukisan karya Sternberg yang diberi nama "Ecco Homo" dalam sebuah galeri seni Dusseldrof Jerman. Di bawah lukisan bergambar Yesus bermahkota duri di hadapan Pilatus itu, terdapat tulisan berbunyi: "Ini Aku lakukan untuk kamu, apa yang kamu lakukan untuk aku?" Walaupun tulisan tersebut tidak bermakna penting bagi si pelukis, tetapi oleh ayahnya, Frances Redley Havergal didorong untuk menulis syair lagu berdasarkan tulisan tersebut. Hal inilah kemudian menjadi ide sumber syair lagu "Nyawa-Ku Diberikan Bagimu" NKI 49.

Kedua, Nyanyian "Nyawa-Ku Diberikan Bagimu" adalah himne atau nyanyian yang masih digunakan dalam peribadahan gereja. Nyanyian ini selalu dibawakan pada saat ibadah perjamuan kudus, untuk mengingat dan memperingati pengorbanan Yesus di kayu salib. Frasa "Ini Aku lakukan untuk kamu, apa yang kamu lakukan untuk aku?" mengekspresikan pengabdian diri orang percaya dan tantangan lengkap untuk berkomitmen memberi hidup sepenuhnya kepada Yesus. Pengembangan ide ini diekspresikan dalam syair lagu dari bait ke bait dalam bentuk pertanyaan, yang mengokohkan komitmen atau iman orang percaya kepada Yesus, berdasarkan ayat-ayat Alkitab sebagai pendukung syair lagu.

${ }^{80}$ Asih Rachmani Endang Sumiwi, "Peran Roh Kudus Dalam Kehidupan Orang Percaya Masa Kini," Jurnal Teologi Gracia Deo 1, no. 1 (14 Desember 2018): 31, http://EJournal.Sttbaptisjkt.Ac.Id/Index.Php/Graciadeo/Article/View/19.

${ }^{81}$ Jones M. Sagala, "The Role Of The Holy Spirit Di Baptism In The Pauline Epistles," Jurnal Theologia Forum Stft Surya Nusantara 4, no. 1 (30 Juni 2016): 1, http://jurnalstftsunus.ac.id/index.php/stft/article/view/1.

${ }^{82}$ Robert P. Borrong, "Kepemimpinan Dalam Gereja Sebagai Pelayanan,” Voice Of Wesley: Jurnal Ilmiah Musik Dan Agama 2, no. 2 (25 November 2019): 4, https://doi.org/10.36972/jvow.V2i2.29. 
Ketiga, pokok pikiran atau tema dari lagu "Nyawa-Ku Diberikan Bagimu" terletak pada kor yang terdapat pada dua baris terakhir di setiap bait lagu. Sebagai himne atau nyanyian jemaat, lagu ini juga digolongkan sebagai nyanyian rohani atau nyanyian Injili; nyanyian yang bersifat kesaksian. Pengulangan kata yang sama pada setiap bait, yaitu, "apa kau b'ri pada-Ku?," adalah frasa terakhir yang menjadi pokok pikiran atau inti dari keseluruhan lagu. Apa kau B'ri pada-Ku? adalah ungkapan pertanyaan yang sesungguhnya, jawabannya sudah ada pada pernyataan setiap frasa syair dari ke empat bait lagu. Pengembangan ide yang menggambarkan 'dialog' imajinasi Frances atas derita Yesus, bukan 'tuntutan' Yesus secara langsung kepada manusia. Frasa "apa kau beri pada-Ku," menjadi bagian penting dalam lagu ini, karena mendorong orang percaya mengaplikasikan pengorbanan Yesus dalam kehidupannya agar menjadi pribadi yang memuliakan Allah. Orang percaya tidak dituntut timbal balik dari karya Kristus, namun responsif manusia menerima pendamaian atau pengorbanan itu dilakukan dalam kehidupan sesama manusia.

Keempat, lagu "Nyawa-Ku Diberikan Bagimu" NKI 49, adalah lagu yang sudah lama dikenal dengan makna syair yang sangat memberkati. Lagu ini tetap mengacu kepada kepribadian Yesus yang menyelamatkan manusia dari belenggu dosa. Dalam peribadatan Gereja Kemah Injil Indonesia, lagu "Nyawa-Ku Diberikan Bagimu NKI 49" hingga saat ini masih digunakan sebagai nyanyian, terutama pada ibadah perjamuan kudus. Biasanya dinyanyikan sebagai lagu penghantar pelaksanaan perjamuan. Nyanyian juga menjadi salah satu sarana penting dalam pemberitaan Injil dan pengenalan akan Kristus. Pengaplikasian dalam kehidupan sehari-hari menjadi hal utama bagi setiap orang percaya yang sangat diberkati, dan kehidupan yang diberkati yang dapat diperlihatkan dengan cara: mengucap syukur, hidup dalam persekutuan, menjadi saksi Kristus, dan menghasilkan buah. 


\section{DAFTAR PUSTAKA}

Alkitab. Lembaga Alkitab Indonesia. Jakarta: 2015.

Akmal. "Kebudayaan Melayu Riau (Pantun, Syair, Gurindam)." Jurnal Dakwah Risalah 26, no. 4 (2015): 159-165. https://doi.org/10.24014/jdr.v26i4.1283.

Anjani, Karina. Apa Itu Musik. Tanggerang Selatan: Marjin Kiri, 2014.

Ara, Alfonsus. "Upaya Mencari Gambaran Yesus yang Bercorak Keasiaan.” Jurnal Logos 8, no. 1 (2011): 39-59. Bakker, F. L. Sejarah Kerajaan Allah 1. Jakarta: BPK Gunung Mulia, 2007.

Borrong, Robert P. “Kepemimpinan Dalam Gereja Sebagai Pelayanan.” Voice Of Wesley:

Jurnal Ilmiah Musik Dan Agama 2, no. 2 (2019): 1-13 https://doi.org/10.36972/jvow.v2i2.29.

Bosch, David J. Transformasi Misi Kristen. Jakarta: BPK Gunung Mulia, 2006.

Burke, James P. Pioneers of Second Fork. America: AuthorHouse, 2009. Bliss, Philip P. Biografi Kristiani. 2 Maret 2020. https://biokristi.sabda.org/philip_p_bliss

Christa, Kevin Maulana. "Persepsi Jemaat Terhadap Musik Iringan Dalam Ibadah Di Gereja

Kristen Indonesia (GKI) Sragen.” Jurnal Pendidikan Seni Musik 5, no. 1 (2016): 1-8. http://journal.student.uny.ac.id/ojs/ojs/index.php/musik/article/view/4070.

Collins, Ace. Stories Behind The Traditions And Songs Of Easter. America: Zondervan, 2009.

Doe, Charles J. The Hymns of Frances Ridley Havergal (Mineapolis: Curiosmith, 2017).

Dannari, Hana Ruben. "Kajian Teologi Tentang Penderitaan Yesus Sebagai Anak Daud." https://doi.org/10.31219/osf.io/x8t6c.

Duewel, Wesley L. Heroes of the Holy Life: Biographies of Fully Devoted Followers of Christ. USA: Zondervan, 2009.

Evert, Jansen Wendell. Memoirs of Philip P. Bliss. New York: Haverd College Libray, 1877.

Ensiklopedi Musik. Jakarta: Delta Pamungkas, 1997.

Giawa, Nasokhili. "Serving Others: Keteladanan Pelayanan Yesus Kristus Berdasarkan Yohanes 13." Integritas: Jurnal Teologi 1, no. 1 (2019): 54-65. http://journal.sttjaffrayjakarta.ac.id/index.php/ji/article/view/9.42

Handayani, Dessy. "Tinjauan Teologis Konsep Iman dan Perbuatan Bagi Keselamatan." Jurnal Teologi dan Pelayanan Kristiani 4, no. 1 (2017): 91-103. http://www.stttorsina.ac.id/jurnal/index.php/epigraphe.

Hasbullah, Ahmad Syai, dan Nurlaili. "Mebobo Pada Adat Perkawinan Suku Kluet Desa Malaka Kecamatan Kluettengah Kabupaten Aceh Selatan.”Jurnal Ilmiah Mahasiswa Pendidikan Seni, Drama, Tari \& Musik 1, no. 1 (2016): 29-37. http://www.jim.unsyiah.ac.id/sendratasik/article/view/5237.

Hidayat, Elvin Atmaja. "Iman Di Tengah Penderitaan: Suatu Inspirasi Teologis-Biblis Kristiani."Melintas 32, no. 3 (2016): 285-308. https://doi.org/10.26593/mel.v32i3.2695.285-308.

Ishak, Lew. Paduan Suara Kebenaran. Surabaya: Kanada Baru, 1966.

Johansson, Calvin M. Discipling Musik Ministry Twenty-First Century Directions. America: Hendrickson Publisher, 2002.

Kamus Besar Bahasa Indonesia. 5 ed. Jakarta: Balai Pustaka, 2016.

Kus'rahkan HidupKu Karnamu (Nyanyian Pujian 304). 2020. https://alkitab.app/np/304.

Laoly, Nepho. "Yesus Dalam Targum Dan Gulungan Laut Mati." Pneustos: Jurnal Teologi Pantekosta 1, no. 1 (2018): 28-40. http://sttpantekostasumutaceh.ac.id/e-journal/index.php/pneustos/article/view/3.

Lasor, W. S., D. A. Hubbard, dan W. F. Bush. Pengantar Perjanjian Lama 1. Jakarta: BPK Gunung Mulia, 2008.

Lele, Aldorio F. dan Robi Panggarra. "Makna Tujuh Ungkapan Yesus Di Salib Bagi Orang Percaya." Jurnal Jaffray 13, no. 2 (2015): 285-316. https://doi.org/10.25278/jj71.v13i2.181. 
Mulia, Hendra G. "Sejarah dan Tinjauan Kritis tentang Teori Kenosis," Jurnal Pelita Zaman 7, no. 1(1992): 1-5. https://alkitab.sabda.org/resource.php?topic=303\&res=jpz.

Maiaweng, Peniel C. D. "Inkarnasi: Realitas Kemanusiaan Yesus." Jurnal Jaffray 13, no.1 (2015): 97-120. https://doi.org/10.25278/ji71.v13i1.114.

Merang, Rose Melly, dan Robi Panggarra. "Makna Kata Kharis Berdasarkan Surat Efesus 2:8 Dan Implementasinya Dalam Kehidupan Orang Percaya Masa Kini.

"Jurnal Jaffray 10, no. 2 (2012): 70-103. https://doi.org/10.25278/jj71.v10i2.54.

Milda, Roy Sari. Pujangga Hujan: Teori Dan Apresiasi Puisi. Banda Aceh: CBK Digital Publishing, 2019.43

Mouw, Richard J. Wonderful Words Of Life: Hymns In American Protestant History And Theology. America: Wm. B. Eerdmans Publishing, 2004.

Nainggolan, Rahmat Hasudungan. "Pengaruh Cara Hidup Jemaat Mula-Mula Berdasarkan Kisah Para Rasul 2:41-47 Dan Relevansinya Pada Masa Kini." Pneustos: Jurnal Teologi Pantekosta 1, no. 1 (2018): 90-108. http://sttpantekostasumutaceh.ac.id/e-journal/index.php/pneustos/article/view/8.

Niftrik, Gerrit Cornelis Van. Dogmatika Masa Kini. Jakarta: BPK Gunung Mulia, 1978.

"Nyanyian Kidung Baru 84." 1 Maret 2020. https://Kidung.Co/?

Oroh, Herwan. "Documents.tips 117 kisah-menarik-lagu-sion." Education, 00:38:43 UTC: 1-130. https://www.slideshare.net/herwanoroh1/documentstips-117kisahmenariklagusion.

Obor, Greria. Iman Katolik: Buku Informasi Dan Referensi. Yogyakarta: Kanisius, 1996.

Patandean, Yohanes Enci, Bambang Wiku Hermanto. "Tema-Tema Theologis Khotbah Yesus Di Bukit Dalam Injil Matius 5:1-7:29.” Evangelikal Jurnal Teologi Injil dan Pembinaan Warga Jemaat 3, no. 2 (2019): 123-135. https://journal.sttsimpson.ac.id/index.php/ejti/article/view/140/pdf.

Pringgodigdo. Ensiklopedi Umum. Yogyakarta: Kanisius, 1991.

Purba, Wagelman. "Karya Penyelamatan Yesus Kristus Dilakukan Dalam Status Kerendahan Matius 1:21 Dan Maknanya Bagi Gereja Masa Kini." Jurnal Pendidikan Religius 1 no. 1 (2019): 22-26. https://jurnal.darmaagung.ac.id/index.php/jurnalreligi/article/view/169.

Randy, Petersen. Be Still, My Soul: The Inspiring Stories Behind 175 Of The Most-Loved Hymns. America: Tyndale House Publishers, Inc., 2014.

Ronda, Daniel. "Doktrin Tentang Surga: Relevansinya bagi Tugas Misi Sedunia." Jurnal Jaffray 12, no. 2 (2014): 199-212. https://doi.org/10.25278/jj71.v12i2.14.

Ryken, Leland, James C. Wilhoit, dan Tremper Longman III. Kamus Gambaran Alkitab. Surab Momentum, 2011. Sagala, Jones M. "The Role Of The Holy Spirit Di Baptism In The Pauline Epistles.” Jurnal Theologia Forum STFT Surya Nusantara 4, no. 1 (2016): 1-14. http://jurnalstftsunus.ac.id/index.php/stft/article/view/1.

Siahaan, Rohani. "Memahami Nyanyian Jemaat Sebagai Sentral Musik Gereja Apa dan Bagaimana?” Jurnal Jaffray 10, no. 2 (2012): 157-165. https://doi.org/10.25278/jj71.v10i2.57.44

Simamora, Adolf Bastian. "Perspektif Biblikal Tentang Agama Dan Kekerasan Dalam Peristiwa Penyaliban Yesus." Voice Of Wesley: Jurnal Ilmiah Musik Dan Agama 1, no. 2 (2018): 1-17. https://doi.org/10.36972/jvow.v1i2.11.

Simanjuntak, Alfred. Kisah Kidung. Jakarta: Yamuger, 2006. Sitowati, Inggit. "Relevansi Selera Musik Klasik dan Kelas-Sosial.” Jurnal Musik 2, no. 1 (2010): 11- 22. https://repository.uksw.edu/bitstream/123456789/2813/2.

Sondakh, Ed. Firman Hidup 36. Jakarta: BPK Gunung Mulia, 2009.

Stephanus, Djuwansah Suhendro P. "Mengajarkan Penginjilan Sebagai Gaya Hidup Orang Percaya." Redominate: Jurnal Teologi Dan Pendidikan Kristiani 1, no. 1 (2019): 12-22. https://sttkerussoindonesia.ac.id/e-journal/index.php/redominate/article/view/2.

Sulastio, Hari. "Keselamatan Karena Kasih Karunia Menurut Efesus 2:1-10.” Antusias: Jurnal Teologi dan Pelayanan 6, no. 1 (Juni 2020): 63-75. https://sttintheos.ac.id/e-journal/index.php/antusias. 
Sumiwi, Asih Rachmani Endang. "Peran Roh Kudus Dalam Kehidupan Orang Percaya Masa Kini. "Jurnal Teologi Gracia Deo 1, no. 1 (2018): 23-31. http://e-journal.sttbaptisjkt.ac.id/index.php/graciadeo/article/view/19.

Susanto, Hery. "Pembebasan Yang Berpihak Kepada Kelompok Marginal." Jurnal Teologi Siap 7, no 2 (2018): 83-190. https://repository.divinity.edu.au/3653.

Tandei, Samuel E. "Tinjauan Historis Perkembangan Musik Gerejawi didalam Gereja Gereja Independen (Free Churches) dan Implikasinya bagi Penatalayanan Musik Gerejawi di Masa Kini (1)." Veritas : Jurnal Teologi dan Pelayanan 15, no. 1 (2014): 81-105. https://doi.org/10.36421/veritas.v15i1.289.

Tanujaya, Jonathan. "Menjadi Pemimpin Musik Gereja Yang Handal." Voice of Wesley: Jurnal Ilmiah Musik dan Agama 2, no. 2 (2019): 1-5. https://dx.doi.org/10.36972/jvow.v2i2.28.

Timotius, Kris H. Pengantar Metodologi Penelitian: Pendekatan Manajemen Pengetahuan untuk Perkembangan Pengetahuan. Yogyakarta: ANDI, 2017.

Tison, dan Jermia Djadi. "Pengajaran Tentang Ibadah Berdasarkan Surat Ibrani 10:19- 25 Dan Implimentasinya Dalam Kehidupan orang Percaya Pada Masa Kini.” Jurnal Jaffray 11, no. 1 (2020): 37-66.

Yulianingsih, Dwiati dan Setiawan, David Eko. "Signifikansi Salib Bagi Kehidupan Manusia dalam Teologi Paulus." Jurnal Teologi Sistematika Dan Praktika 2, no. 2 (2019): 228-246. http://www.stt-tawangmangu.ac.id/e-journal/index.php/fidei.45

Zaluchu, Sonny. "Penderitaan Kristus Sebagai Wujud Solidaritas Allah Kepada Manusia." Dunamis: Jurnal Penelitian Teologi dan Pendidikan Kristiani 2, no. 1 (2017): 61-74. https://doi.org/10.30648/dun.v2i1.129. 